\title{
Reviewer Penelitian untuk Indonesia Maju
}

\section{Didi Sundiman}

Universitas Universal, Indonesia

Sundiman.didi@gmail.com

\begin{abstract}
Artikel ini menunjukkan peran strategis reviewer penelitian dalam proses pengembangan ekosistem penelitian Indonesia sebagai satu negara kesatuan yang terdiri dari banyak pulau, budaya dan faktor demografis lainnya.
\end{abstract}

Keywords: research; reviewer; Indonesia

\section{Integritas Reviewer untuk Keluarga, Bangsa dan Negara}

Seorang reviewer pada esensinya adalah satu individu yang diberi kepercayaan untuk ikut berkontribusi pada proses pengembangan pengetahun melalui proses penelitian. Saya, Didi akan menunjukkan di bawah ini bagaimana pentingnya integritas reviewer sebagai satu individu dikaitkan dengan kepentingan negara dan bangsa.

Pertama, satu individu manusia dilahirkan sebagai kebesaran alam semesta, Tuhan sang maha pencipta untuk bisa ikut berkontribusi mengisi dunia. Setiap individu tumbuh dan berkembang, belajar, menjadi dewasa dalam segala hal kehidupan. Sebagai reviewer maka spesifik peran kita adalah ikut memberikan saran dan masukkan bagi proses penyusunan rencana penelitian yang berkualitas dalam proses pengembangan pengetahuan.

Kedua, dalam berkeluarga, seorang reviewer menjadi teladan keluarga, mendidik generasi penerus untuk bisa mengembangkan karakter integritas dan tanggung jawab.

Ketiga, keilmuan yang telah dibangun, saran dan masukkan yang diberikan dalam banyak rencana penelitian dilaksanakan dengan baik oleh pelaksana penelitian akan memberikan dampak bagi pengembangan keilmuan, menciptakan produk dan karya tepat guna untuk permudah dan peningkatan kualitas hidup masyarakat, masyarakat mendapatkan manfaat maksimal, menuju peradaban yang lebih baik. Masyarakat dengan peradaban lebih baik mampu membangun negara dengan lebih efektif dan efisien, memanfaatkan berbagai sumber daya yang ada secara maksimal, berintegritas untuk kemajuan bangsa dan negara.

Keempat, tidak berhenti sampai bangsa dan negara, integritas reviewer akan membawa peradaban yang lebih baik bagi dunia dan semesta. Kemajuan masing-masing bangsa dari hasil penelitian yang berkualitas akan membawa dunia pada penggunaan sumber daya yang efektif dan efisien, menciptakan dunia damai harmonis, dunia satu keluarga.

Penulis merupakan peneliti di bidang ilmu manajemen dengan beberapa karya publikasi penelitian berupa artikel di jurnal dan prosiding nasional dan internasional bidang knowledge management (Fajarianto, Setiawan, Mursidi, Sundiman, \&Sari, 2018; Sundiman, 2017, 2018; Sundiman \&Idrus, 2015; Sundiman, Wu, Mursidi, Johan, et al., 2019; Sundiman, Wu, Mursidi, \&Ting, 2019)

\section{Wawasan NKRI bagi seorang Reviewer}

Indonesia adalah negara besar, saya pernah berada di Kalimantan, Jawa, Sumatera dan Sulawesi di puluhan kota dari pulau-pulau itu, ya, sekali lagi negara Indonesia adalah negara besar. Reviewer harus memiliki pandangan holistik dan menyeluruh pada NKRI, sebagai satu kesatuan tak terpisahkan dari 
setiap komponen di dalamnya. Ribuan pulau, ratusan suku dan bahasa, banyak keyakinan merupakan bagian tak terpisahkan sebagai satu identitas, Indonesia.

Seorang reviewer harus bisa menempatkan diri sebagai Indonesia, tidak sebagai individu yang berasal dari daerah, suku, atau keyakinan tertentu, namun sebagai Indonesia. Seorang reviewer mampu melihat semua perbedaan dan jarak yang ada sebagai warna warni yang menghias Indonesia.

Seorang reviewer mampu membangun komunikasi yang baik dengan semua pihak, semua komponen dalam lingkungan penelitian, membuka wawasan kebangsaan yang utuh pada NKRI, ingat, samudera luas Indonesia bukanlah pemisah banyak pulau kita, samudera Indonesia adalah penyatu Indonesia raya yang telah dibuktikan oleh nenek moyang bangsa kita, semua pejuang yang mencurahkan jiwa raga dan darah untuk Indonesia yang berdaulat, Negara Kesatuan Republik Indonesia yang akan maju dan jaya di masa depan, ikut berperan aktif mewujudkan dunia damai harmonis, dunia satu keluarga.

\section{References}

Fajarianto, O., Setiawan, M. I., Mursidi, A., Sundiman, D., \&Sari, D. A. P. (2018). The Development of Learning Materials for Introduction of Animals in Early Childhood Using Augmented Reality. In L.Uden, B.Hadzima, \&I.-H.Ting (Eds.), Knowledge Management in Organizations (pp. 722-727). Cham: Springer International Publishing. Retrieved from https://link.springer.com/chapter/10.1007/978-3-319-95204-8_60

Sundiman, D. (2017). Human Resource Management in the Enhancement Processes of Knowledge Management. Binus Business Review, 8(3), 167-173. https://doi.org/10.21512/bbr.v8i3.3708

Sundiman, D. (2018). The Effect of Knowledge Management on the Strategic Management Process Mediated by Competitive Intelligence in the Small Business Company. Jurnal Manajemen Dan Kewirausahaan, 20(2), 105-115. Retrieved from http://jurnalmanajemen.petra.ac.id/index.php/man/article/view/21104

Sundiman, D., \&Idrus, M. S. M. (2015). Confucianism ethic, Guanxi, and acculturation role on the knowledge transfer process of Chinese descendant in Indonesia. International Journal of Knowledge Management Studies, 6(3), 261. https://doi.org/http://dx.doi.org/10.1504/IJKMS.2015.072712

Sundiman, D., Wu, C. H., Mursidi, A., Johan, S. B. P., Indahingwati, A., \&Putra, S. S. (2019). Knowledge management key factors: an empirical research on small and medium-sized enterprises in Indonesia. International Journal of Business and Systems Research, 13(2), 139-161. https://doi.org/10.1504/IJBSR.2019.098650

Sundiman, D., Wu, C. H., Mursidi, A., \&Ting, I.-H. (2019). Task-Individual-Social Software Fit in Knowledge Creation Performance. International Journal of Knowledge Management, 15(2), 3654. https://doi.org/10.4018/ijkm.2019040103 